\title{
HADIS AZIMAT PERSPEKTIF SEMIOTIK ROLAND BARTHES
}

\author{
Syafi'ul Huda \\ UIN Sunan Kalijaga Yogyakarta \\ khuzakhan19@gmail.com
}

\begin{abstract}
ABSTRAK
Sebagai negara berbudaya, nenek moyang bangsa Indonesia mewariskan banyak sekali peninggalan-peninggalan yang terrepresentasikan dalam norma dan benda. Mengenai norma, keharmonisan bangsa Indonesia yang multikultural, multietnis, dan multireligion sudah menjadi bukti yang tidak terbantahkan. Lain halnya dengan penginggalan yang berupa kebendaan. Sebagiannya masih menyisakan perdebatan yang tidak berujung saat dipertemukan dengan agama. Azimat misalnya, sebagian masyarakat menilainya sebagai unsur kemusyrikan yang harus dihindari. Sementara mayoritas masyarakat yang ada tidak mempermasalahkan penggunaannya selama hal itu sesuai dengan ketentuan yang digariskan ulama. Pandangan kedua kelompok ini didasarkan pada sumber yang sama yakni hadis Nabi Muhammad saw. Hanya saja pendekatan yang digunakan dalam memahaminya sama sekali berbeda hingga pada akhirnya mereka sampai pada pandangan masing-masing. Penurunan bagian-bagian yang muncul dalam pemahaman dua kelompok ke dalam bagan-bagan yang disediakan Roland Barthes dalam semiologi mitosnya sangat membantu masyarakat awam untuk mengenali dua pandangan ini.
\end{abstract}

Kata Kunci: Hadis Azimat, Tabarruk, Syirik, Mitos Roland Barthes

\begin{abstract}
As a cultured country, the ancestors of the Indonesian people bequeathed a lot of relics that are represented in norms and objects. Regarding norms, the harmony of the Indonesian nation which is multicultural, multiethnic, and multireligious has become irrefutable evidence. It is different with relics in the form of material. Some of them still leave endless debates when they are met with religion. Amulet, for example, some people consider it as an element of polytheism that must be avoided. Meanwhile, the majority of the
\end{abstract}


existing community has no problem with its use as long as it is in accordance with the provisions outlined by the pious scholar. The views of these two groups are based on the same source, namely the hadith of the Prophet Muhammad (Peace be upon Him). Nevertheless, the approaches used in the understanding are completely different, so that they have their own prespective views. The derivation of the passages that appear in the understanding of the two groups into the charts provided by Roland Barthes in his mythical semiology is very helpful for ordinary people to recognize these two views.

Keywords: Azimat, Hadith, Tabarruk, Shirk, Myth of Roland Barthes

\section{A. PENDAHULUAN}

Indonesia merupakan negara yang kaya akan budaya. Keragaman budaya ini tertuang dalam gagasan, nilai-nilai, norma-norma, peraturan, sistem sosial, dan benda-benda hasil karya manusia (Machmudah, 2016, p. 187). Keris misalnya, sebagai budaya asli Indonesia nasibnya hampir sama dengan batu akik, ikan arwana dan tanaman gelombang cinta yang sempat menjadi obyek demam sosial (Meganingrum \& Fauziah, 2017, p. 368). Hanya saja dia lebih baik dan terhormat, tidak sembarang orang mampu dan bisa mengoleksinya. Pasalnya, ada semacam kejodohan atau kecocokan antara keris dengan pemiliknya. Belum lagi mas kawin yang harus dikeluarkan untuk meminangnya. Ia tidak hanya dianggap sebagai senjata dalam pengertian simbolik atau spiritual, melainkan juga dianggap memiliki kekuatan gaib yang bisa menambahkan keberanian, percaya diri, menghindarkan serangan wabah dan hama, menyingkirkan dan menangkal gangguan makhluk halus, memudahkan urusan, dan memberi keselamatan (Purwadi \& et.al, 2005, p. 240-241). Dalam budaya Indonesia, sesuatu yang memiliki kekuatan tertentu ini dikenal dengan istilah azimat (Dwiatmojo, 2018, p. 86).

Keberadaaan keris dengan kedudukan yang spesial ini, yakni sebagai azimat, tidak bisa lepas dari sebagian umat Islam Indonesia sebagai masyarakat mayoritas. Sementara itu, Islam sangat keras terhadap mereka yang meyakini akan adanya kekuatan selain kekuatan Allah. Mereka percaya bahwa selain Allah masih ada sesuatu di alam ini baik berwujud material maupun immaterial, yang mampu mendatangkan manfaat dan mudarat terhadap diri manusia dan alam ini (Umar, 2014, p. 233-234). Pandangan dan keyakinan yang demikian ini disebut dengan istilah syirik. Dari sini muncul pandangan miring dari segolongan umat Islam Indonesia terhadap saudaranya yang masih gemar mengoleksi benda pusaka ini. Mereka yang terkenal keras dan kaku dalam memahami agama ini tidak segan-segan mensyirikkan saudaranya bahkan menilainya telah keluar dari Islam (Muhammad, 2012, p. 80). Mereka selalu mengajak umat Islam untuk kembali pada al-Qur'an dan hadis. Padahal, mayoritas umat Islam tidak mengamalkan ajarannya secara langsung dari 2 sumber utama ini. Mereka mengadopsi hasil pemahaman ulama atau tokoh masyarakat yang berhasil memahami isi dan kandungan ajaran Islam dari sumber pokok (al-Qur'an dan hadis) dengan relatif baik (Khaziq, 2009, p. 13). 
Banyak sekali pengkaji azimat yang menggunakan kaca mata agama dan budaya sebagai pisau pembedahnya. Ada yang membahasnya dari sisi pembuatan azimat berdasarkan agama. Hal ini sebagaimana yang dilakukan Zamzami yang diantaranya berkesimpulan bahwa Islam memiliki cara tesendiri selain giat bekerja dalam membantu umatnya terbebas dari kefakiran (Zamzami, 2018). Ada juga tulisan yang membahas naskah kitab yang ditengarai mengandung azimat dan rajah. Berkaitan dengan kajian naskah ini, Dwiatmojo misalnya menemukan adanya 32 azimat dan rajah dalam naskah CPTN (Catatan Pengikut Tarekat Naqsabandiyah) dalam bentuknya yang bervariasi dan fungsinya yang beragam (Dwiatmojo, 2018). Ada yang mengkajinya dari sisi penggunaannya sebagai pelaris dagangan menurut akidah Islam sebagaimana yang dilakukan Sahad (Sahad, 2015). Muncul juga penelitian mengenai azimat dari sisi pergeseran nilai skaralitasnya menjadi aksesoris jari (Hs, 2017) dan hubungan antara identitas sosial dengan perilaku konsumtif suatu masyarakat (Meganingrum \& Fauziah, 2017). Dua tulisan terakhir ini muncul sebagai respon terhadap maraknya fenomena demam sosial batu akik di masyarakat Indonesia. Untuk melengkapi kajian-kajian yang sudah ada ini, penulis tertarik untuk membahas azimat dari sisi kebahasaan. Pisau yang akan digunakan dalam kesempatan ini adalah semiotik Roland Barthes. Menurutnya kebudayaan yang diantaranya berupa azimat, itu seperti sistem bahasa yang bisa dibaca layaknya sebuah teks. Dan bahasa merupakan sistem tanda yang menggambarkan pendapat-pendapat dari masyarakat dengan waktu-waktu tertentu (Sulaichah, 2019, p. 27).

Dalam artikelnya ini, penulis mencoba mengetengahkan 2 problem yang dinilainya relevan dengan tema tulisan ini. Pertama, bagaimanakah bentuk semiotik azimat menurut Roland Barthes? Kedua, bagaimana pandangan hadis terhadap azimat?. Untuk membantu pemahaman yang komprehensif atas sumber kedua Islam ini, penulis akan menelusuri pemahaman ulama terhadap naskah hadis seputar azimat yang ditemukan. Adapun alat bantu yang akan digunakan dalam penelusuran ini adalah kitab al-Wajūz fi Ta'rîf Kutub al-Hadìs karya Sayyid Abdul Mājid al-Gūrī (al-Gūrī, 2009). Menilik tema dan sumber informasinya, tulisan ini tergolong penelitian kualitatif. Kajiannya berorientasi pada sumber tertulis kendati dalam penggunaannya melibatkan subyek di lapangan. Teknik yang digunakan untuk menguliti data temuan adalah analisis semiotika dengan metode deskriptif sebagai penyajiannya.

\section{B. SEMIOTIK AZIMAT MENURUT ROLAND BARTHES}

\section{Roland Barthes Dan Rihlah Ilmiahnya}

Filusuf kelahiran Perancis 12 November 1915 adalah putra dari Louis Barthes dan Barthes Henriette. Ayahnya yang seorang angkatan laut meninggal saat Barthes masih kecil. Ia hidup bersama ibu beserta nenek dan kakeknya (Barthes, 2010). Ia divonis menderita penyakit TBC saat berusia 28 tahun. Saat belajar di Universitas Sorbonne, Barthes fokus pada kajian sastra Perancis dan Klasik (Yunani dan Romawi). Sebelum kembali di negaranya, setelah selesai kuliahnya Barthes menjadi pengajar dalam studi bahasa dan sastra di beberapa tempat seperti Rumania dan Mesir. 
Kemudian di tanah kelahirannya ia mengajar di Ecole Des Hautes en Sciences Sociales. Di perguruan tinggi Perancis yang khusus mempelajari ilmu-ilmu soisal ini Barthes mengajar studi sosiologi tanda, simbol dan representasi kolektif serta kritik semiotika. Selain itu Roland Barthes juga bekerja di pusat nasional penelitian ilmiah (Centre National de Recherche Scientifique) di bidang sosiologi dan leksiologi. Dari sinilah Roland Barthes banyak menulis hal-hal yang berhubungan dengan sastra. Pada tahun 1976, Roland Barthes mendapat gelar sebagai professor "semiology literer" di College de France (Kaelan, 2017, p. 199). Dengan gelar tersebut, Roland Barthes dikenal sebagai tokoh semiologi dari Perancis yang berada pada bagian fase strukturalisme menuju fase pascastrukturalisme sekitar tahun 1960-1970. Pemikirannya mengacu pada struktural dalam sistem tanda yang ada pada budaya dengan menitiktemukan antara linguistik (ilmu bahasa) dan penelitian budaya untuk di analisis dengan semiologi (penetapan makna dalam budaya) (Sulaichah, 2019, p. 25). Barthes meninggal dalam usia 64 tahun pada 26 Maret 1980 pasca kecelakaan yang menimpanya dijalanan Paris sebulan sebelumnya (Barthes, 2010).

Barthes dikenal sebagai tokoh semiotika signifikasi. Ia memperkenalkan istilah signifikasi (signification) atas ditemukannya kecocokan antara penanda dan petanda (komponen penyusun tanda menurut Saussure) yang diperoleh melalui relasi sintagmatis dan paradigmatis (Mubarak, 2007, p. 101). Selain itu, Barthes juga dikenal sebagai tokoh semiotika konotasi. Menurutnya, selain makna denotasi, tanda yang disampaikan juga harus mendapatkan makna Konotasi (Sulaichah, 2019, p. 33). Denotasi menggambarkan relasi antara penanda dan petanda di dalam tanda, dan antara tanda dengan referennya dalam realitas eksternal (Friske, 2007, p. 118). Sementara konotasi merupakan pengembangan segi petanda ("makna") oleh pemakai bahasa. pada saat konotasi menjadi mantap, ia akan berubah menjadi mitos. Banyak sekali fenomena budaya yang dimaknai dengan konotasi yang pada akhirnya berubah menjadi mitos karena kemantapan makna itu dan pada tahap berikutnya berubah menjadi ideologi lantaran semakin mantapnya makna tadi (Sobur, 2014, p. 179). Mengadopsi pandangan Louis Hjelmslev, Barthes membuat konsep tentang bagaimana sebuah tanda bekerja. Menurut Barthes, mitos merupakan sistem semiologi tingkatan kedua (metabahasa) dengan membahas bahasa tingkatan pertama terlebih dahulu. Pada tanda tingkatan pertama, penanda dan petanda menghasilkan makna denotatif yang akan menjadi penanda pada tanda tingkatan kedua yakni mitologi (Sulaichah, 2019, p. 33).

Selain Louis Hjelmslev, dalam menelorkan teori semiologinya Barthes juga dipengaruhi oleh ilmuwan lain. Pertama, Ferdinand De Saussure yang menekankan semiologinya pada ilmu tanda dan pengembangan tanda bahasa (Sudjiman \& Zoest, 1996, p. 56). Semiologinya yang berhenti pada penandaan dalam tingkat denotatif membuat Barthes tertarik untuk melanjutkannya pada tingkat konotatif. Sehingga dapat dikatakan bahwa Barthes adalah penyempurna semiologi Saussure (Sulaichah, 2019, p. 40). 
Kedua, Karl Marx yang memiliki teori ideologi ${ }^{1}$ (Sulaichah, 2019, p. 41-42). Mitos yang diperkenalkan Barthes memiliki hubungan yang kuat dengan ideologi. Marx mendefinisikan ideologi sebagai sebuah kesadaran yang tidak sesuai dengan kenyataan atau kesadaran palsu (Takwin, 2009, p. 58). Barthes mengkaji makna ideologi dari sudut pandang linguistik terutama semiotika yang darinya ia mengembangkan pengertian tentang mitos (Takwin, 2009, p. 104).

\section{Semiologi Dan Mitos Roland Barthes}

Semiologi merupakan bagian dari ilmu filsafat yang membahas tentang tanda yang digunakan untuk menganalisis makna dalam budaya (Sulaichah, 2019, p. 26). Salah satu tokohnya adalah Roland Barthes yang memandang semiologi dan semiotika sebagai dua ilmu yang sama. Baginya, sebuah tanda bsia menunjuk pada sesuatu selain dirinya sesuai dengan pandangan seseorang. Dari sini, nampak adanya hubungan antara teori yang diperkenalkan Barthes dengan teori simbol, bahasa dan wacana (Kaelan, 2017, p. 163). Semiologi Barthes merupakan pengembangan dari teorinya Ferdinand De Saussure (semiolog strukturalis) yang menganalisis sebuah tanda dan mencari hubungan antara penanda dan petanda. Menurut Saussure, tanda (sign) terdiri dari dua hal; penanda (signifier) dan petanda (signified). Penanda atau bentuk (form) merupakan aspek material tanda yang bisa ditangkap oleh indera manusia. Petanda atau konsep (concept) merupakan aspek mental dari tanda, yang biasa disebut sebagai konsep, yang muncul dalam pikiran atau ungkapkan penutur. Petanda bukanlah sesuatu yang dituju oleh tanda melainkan representasi mentalnya (Budiman, 2011, p. 30).

Term mitos berasal dari bahasa Yunani, muthos yang berarti cerita. Yakni cerita dalam bentuk ungkapan atau tuturan yang banyak dibicarakan dan dipercayai banyak orang secara turun menurun, melekat dalam budaya dan tradisi masyarakat namun tidak mampu untuk dibuktikan kebenarannya. Adapun mitos menurut Barthes adalah pemaknaan, tipe wicara, atau ungkapan yang menyampaikan pesan dalam budaya massa. Bagian yang dikritik Barthes dengan analisis semiologinya adalah pesan mitos itu sendiri yang dalam hal ini bukan intrinsiknya melainkan hasil konstruksi penandaannya (Sulaichah, 2019, p. 29).

Lahirnya sebuah mitos terjadi karena adanya penanda dan petanda yang dimutlakkan. Secara konotasi, makna itu banyak namun hanya satu

\footnotetext{
1Di dalamnya terdapat pemutarbalikan fakta. Yakni menggambarkan kenyataan (yang tidak semestinya) melalui interpretasi yang dibalik dengan tujuan yang tidak baik, untuk diungkapkan dan diusahakan sebaik mungkin agar terlihat baik dimata masyarakat. Karena adanya kebutuhan dan keinginan manusia, pandangan-pandangan seperti ini muncul dalam kehidupan masyarakat, akan tetapi masyarakat tidak menyadarinya sebagai kepalsuan. Bagi Marx, fungsi ideologi adalah mendukung kepentingan kelas tertentu dalam masyarakat agar bisa diyakini dan diterima oleh masyarakat secara umum. Ideologi selalu muncul dalam pembentukan mitos. Mitos akan berkembang menjadi ideologi jika kehadirannya diterima oleh masyarakat. Menurut Barthes mitos itu "bourgeoisie" dan berfungsi menaturalkan tatanan sosial yang ada. Kelompok "bourgeoisie" atau borjuis merupakan sekelompok masyarakat yang diuntungkan oleh sistem ideologi ini. Bisa dikatakan kelompok ini merupakan produsen dalam artian pembuat mitos.
} 
makna yang paling benar dan dipercayai banyak orang. Makna inilah yang disebut sebagai mitos. Semua ungkapan atau tuturan bisa dijadikan mitos, akan tetapi mitos itu akan terganti dengan mitos yang baru dan lebih kuat sesuai dengan perkembangan zaman. Hal ini karena konsep yang ada pada mitos bisa berubah, diciptakan kembali, diuraikan, berkembang ataupun tenggelam hilang dengan sendirinya (Sulaichah, 2019, p. 35). Dari sisi perubahan ini mitos bersifat dinamis (Friske, 2007, p. 125).

Prinsip utama mitos adalah mengubah sejarah menjadi alamiah. Hal ini dapat ditangkap melalui ketidaksadaran masyarakat (konsumen mitos) akan motivasi dan kepentingan yang tersembunyi di dalam sebuah mitos (Takwin, 2009, p. 105). Interpretasi sangat dibutuhkan dalam memahami mitos. Pada mitos terjadi proses penafsiran secara alami yang memunculkan pandangan-pandangan tertentu lewat sejarah dan tidak dapat ditolak karena terjadi secara alami (Sulaichah, 2019, p. 31). Pandangan tertentu yang tidak begitu mendalam inilah yang membuat masyarakat tidak lagi memahami pesan dibalik sebuah mitos. Sehingga dibutuhkan pembongkaran dan uraian terhadap sebuah mitos demi ditemukannya makna sebenarnya yang bersembunyi dibalik mitos tersebut.

Barthes beranggapan bahwa mitos merupakan sistem semiologis tahap kedua (bahasa tingkatan kedua) yang membahas tahap pertama (bahasa tingkatan pertama). Pada tahap pertama terdapat penanda dan petanda yang akan membangun makna denotasi dan akan menjadi penanda pada tahap kedua serta makna konotasi yang akan melahirkan mitos. Dari sini, mitos bisa dipahami sebagai wacana konotasi dalam proses signifikasinya (Sulaichah, 2019, p. 34).

Mengenai pertandaan, Barhes mengusulkan dua tingkatan pertandaan, yaitu tanda pada tingkat bahasa dan tanda pada tingkat mitos atau ideologi (Rahtikawati \& Rusmana, 2013, p. 336). Menurut Roland Barthes terdapat dua analisis semiologi untuk menganalisis sebuah mitos, yaitu:

a. Analisis Pertama

Analisis pertama terdiri dari tiga unsur yakni tanda (sign), penanda (signifier) dan petanda (signified). Analisis dalam tataran bahasa (sistem semiologi tingkatan pertama) ini menganalisis hubungan antara penanda dengan petanda yang menghasilkan tanda.

b. Analisis Kedua

Analisis kedua yang terjadi dalam tataran mitos (sistem semiologis lapis kedua) menjadikan tanda pada tataran bahasa sebagai penanda yang berhubunan lagi dengan petanda. Berikut penjelasan masing-masing dari tanda (makna), penanda (bentuk) dan petanda (konsep) (Budiman, 2011, p. 38-39)

Berikut ini gambaran bagan daripada semiologi yang diperkenalkan Barthes (Barthes, 2010, p. 303). Bahasa tingkat pertama terdiri dari penanda, petanda dan tanda dengan angka latin $(1,2,3)$. Sementara bahasa tingkat kedua atau mitos meliputi penanda, petanda dan tanda dengan angka romawi (I, II, III): 


\begin{tabular}{|c|c|c|c|}
\hline \multirow[t]{2}{*}{ Bahasa } & 1. Penanda & 2. Petanda & \\
\hline & \multicolumn{2}{|l|}{$\begin{array}{l}\text { 3. Tanda } \\
\text { I. Penanda }\end{array}$} & II. Petanda \\
\hline Mitos & \multicolumn{3}{|l|}{ III. Tanda } \\
\hline
\end{tabular}

Gambar 1. Semiologi Roland Barthes

\section{PANDANGAN HADIS TERHADAP AZIMAT}

\section{Azimat Sebagai Representasi Budaya}

Azimat sebagai hasil karya manusia dalam bentuk benda merupakan satu dari tiga representasi budaya yang diwariskan oleh generasi masa lalu (Machmudah, 2016, p. 187). Azimat atau jimat adalah 'barang-barang sing dianggêp duwe daya sing ngungkuli kodrat' segala sesuatu yang mempunyai kekuatan yang lebih dari biasanya (Dwiatmojo, 2018, p. 86). Ia juga dipahami sebagai benda keramat atau benda pusaka yang dipercaya memiliki kekuatan gaib sehingga dapat membantu menyelesaikan segala persoalan hidup (Nurdin, 2015, p. 169). Menurut James George Frazer penggunaan seseorang terhadap sesuatu yang mengandung unsur magic merupakan efek dari ketidakmampuannya mengelola masalah kehidupan dengan baik. (Zamzami, 2018, p. 308). Oleh Suyono kepercayaan semacam ini termasuk kategori fetitisme, yakni pemujaan kepada benda berwujud yang tampak memiliki jiwa (Suyono, 2007, p. 1). Kepercayaan semacam ini juga disebut dengan istilah dinamisme yang menjadi ciri kepercayaan masyarakat primitif. Dinamisme merupakan kepercayaan yang menganggap bahwa setiap benda dapat ditempati oleh kekuatan sakti yang bisa memberikan manfaat atau malapetaka pada manusia (Nasution, dkk, 1992, p. 64). Azimat merupakan salah satu fenomena yang terjadi di berbagai kebudayaan (Dwiatmojo, 2018, p. 102) seluruh bangsa dan etnik di belahan dunia manapun (Sahad, 2015, p. 19).

Dari segi sumber, terdapat dua macam azimat; syar'i dan tidak syar'i. Azimat syar'i adalah azimat yang dalam pembuatan dan penyusunannya menggunakan ayat atau asma Allah yang jelas maknanya baik dengan dibacakan atau ditulis, dan tidak mengandung unsur kemusyrikan. (Sahad, 2015, p. 25). Diantara bentuk jimat adalah wifiq (Sahad, 2015, p. 32), rajah, isim, dan hizib. Wifiq yang di Eropa dikenal dengan magic square, merupakan tulisan yang terdiri dari angka-angka yang diletakkan dalam kotak-kotak yang diyakini memiliki khasiat tersendiri. Wifiq, sesuai kata wafaqa (cocok) dalam bahasa Arab, memiliki kecocokan dalam angka yang dihasilkan dari penjumlahan secara vertikal horizontal kolom-kolomnya (Nurdin, 2015, p. 169-172). Wifiq juga berarti suatu tulisan yang terdiri dari ragam angka, huruf, atau kata yang disusun secara sistematis mengikuti kaidah yang sudah ditentukan untuk membentuk pola enargi yang diinginkan (Zamzami, 2018, p. 321). Rajah adalah gêgambaran utw. tulisan ing dluwang lsp. dianggo jimat; (gambar atau tulisan di kertas dan selainnya yang digunakan sebagai jimat (Dwiatmojo, 2018, p. 86). Atau kumpulan 
tulisan huruf Arab yang terpisah-pisah, baik yang ditulis dalam bentuk kotak-kotak maupun tanpa kotak-kotak. Isim adalah nama yang tidak memiliki makna dalam bahasa Arab yang kadang diyakini sebagai nama Allah, Nabi, Malaikat, atau nama khodam dari bagnsa jin. Adapun hizib merupakan sejenis wirid (amalan) atau senjata yang memiliki khasiat tertentu. adapula jimat yang berbentuk batu akik sebagaimana batu akik berbentuk kepada belut yang pernah dimiliki Ponari (Nurdin, 2015, p. 169172) dan keris milik Jenderal Sudirman. (Nurdin, 2015, p. 169-172), (Pamungkas, 2007, p. 13).

\section{Azimat Dalam Sorotan Hadis Nabi}

Seorang nabi dari suatu agama - menurut Friediche, sosiolog naturalism adalah orang yang mengkritik dunia sosialnya dan mendengungkan kebutuhan perubahan untuk mencegah malapetaka di masa mendatang. Hal ini mengisyaratkan bahwa sabda yang ada adalah untuk memajukan dan mereforasi masyarakat. Karenannya pemahamannya juga harus progresif dan akomodatif dengan kondisi sosiologis masyarakat kontemporer (Mustaqim, dkk., 2008, p. 7). Dengan cara ini, kehadiran ruh dariapada hadis yang merepresentasikan sabda dan ajarannya bisa hadir kapanpun di tengah-tengah masyarakat yang multikultural. Dalam memahaminya, banyak sekali pendekatan yang bisa digunakan. Alfatih (2017, p. 15-111) menyebutkan empat pendekatan; bahasa, historis, sosiologis, dan antropologis. Nizar Ali menambahkan dua macam pendekatan yang lain, yakni sosio-historis dan psikologis (Ali, 2001, p. 29108). Lain lagi dengan Komarudin yang menawarkan tiga pendekatan dalam memahami hadis. Pertama, pendekatan yang menekankan pada gramatika bahasa. Pendekatan ini berangkat dari pemikiran bahwa bahasa dan budaya memiliki ciri lokal dan unik sehingga untuk mengetahui budaya sebuah masyarakat, seseorang harus menyelami sedalam-dalamnya sifat bahasa yang digunakan. Kedua, pendekatan yang menekankan pada konteks sejarah dimana teks itu muncul, yang disebut dengan pendekatan kontekstualhistoris. Ketiga, pendekatan yang menekankan penafsiran falsafi yang cenderung membangun proposisi universal terhadap logika (Nadia, 2017, p. 173).

Dari sekian riwayat yang ada, bisa kita ketahui bahwa azimat sudah dikenal oleh masyarakat jahiliah. Nabi tidak memandang budaya tersebut sebagai sesuatu yang harus disapu bersih dan ditinggalkan secara total. Sebagaimana yang dikisahkan oleh sahabat 'Umair pembantu Abu al-Lahm. Dalam riwayat tersebut Nabi mencermati redaksi mantra yang diperlihatkan kepadanya. Setelah dipilah-pilah Nabi mempersilahkan penggunaan mantra tersebut untuk dipergunakan sebagaimana sebelumnya. (al-Bannā, n.d., p. 178). Berdasarkan hadis Nabi, bentuk daripada representasi budaya Arab saat itu adalah ruqā (mantra atau jampi-iampi) tiwalah (pelet), tamìmah (kalung) (al-Sijistānī, n.d., p. 426, 1997, p. 137), dan wāhinah atau gelang (ibn Hambal, 1999a, p. 204). Kini, tamā ‘im yang dahulu bermakna kalung keselamatan telah mengalami perluasan makna, yakni segala bentuk azimat yang dikenal masyarakat (al-Bannā, n.d., p. 186). Berikut hadis Nabi yang digunakan untuk pengharaman azimat: 


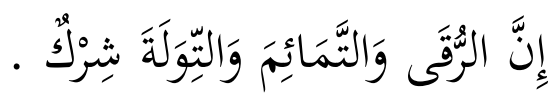

Artinya:

"Sesungguhnya mantera-mantera, jimat, dan pelet adalah syirik" (HR. Abu Dawud).

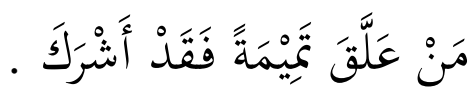

Artinya:

"Barang siapa menggunakan azimat, sesungguhnya ia telah mensekutukan Allah" (HR. Ahmad).

Hadis pertama diriwayatkan Imam Abu Dawud dari sahabat Abdullah bin Mas'ud dalam Kitāb al-Tỉbb Bāb Ta’tīq al-Tamā `im dari Sunan-nya. Dalam hadis ini terdapat percakapan antara sahabat Abdullah bin Mas'ud dengan Zainab istrinya. Saat itu mata Zainab bermasalah kemudian ia berobat kepada seorang Yahudi dan sembuh. Sahabat Nabi ini berkata bahwa sakit mata tersebut termasuk tipu muslihat setan (alSaharanfūrī, n.d., p. 212). Hadis kedua diriwayatkan oleh Imam Ahmad dari sahabat 'Uqbah bin 'Āmir al-Juhanī dalam Musnad-nya. Hadis dengan nomor 17422 ini menceritakan pembaiatan Nabi terhadap rombongan sahabat yang ingin berbaiat. Semua dibaiat - sebagaimana dikisahkan dalam hadis ini - kecuali satu orang yang memakai tamīmah. Nabi baru berkenan membaiatnya setelah ia melepaskan tamimah tersebut. Menurut al-Arna 'ūt, kualitas sanad hadis yang juga diriwayatkan oleh al-Ṭabrābī dan al-Ḥākim dengan redaksi berbeda ini kuat (ibn Hambal, 1999b, p. 637).

Adapun hadis Nabi yang dijadikan dasar pelegalan azimat misalnya adalah apa yang diriwayatkan Imam Muslim dengan nomor hadis 5624 dan 5625 (al-Naisābūrī, 2003, p. 1101), Imam Ahmad dalam Musnad-nya dengan nomor hadis 14382 (ibn Hambal, 1999c, p. 279), dan Abu Dawud dengan nomor hadis 3886 (al-Sijistānī, n.d., p. 426). Adapun bunyi hadis Nabi tersebut adalah:

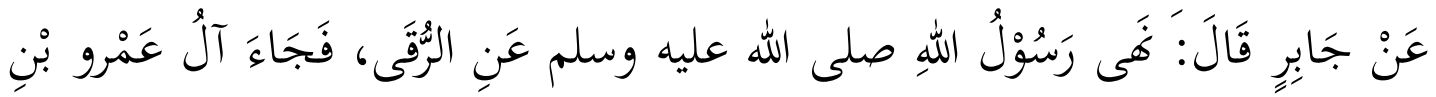

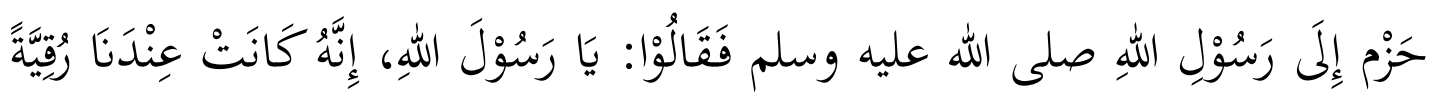

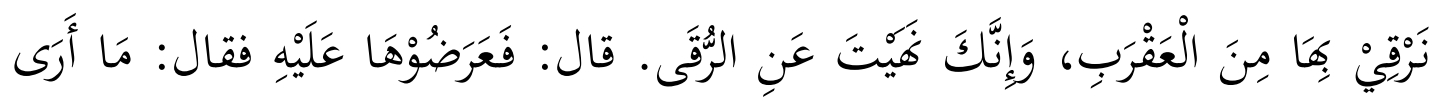

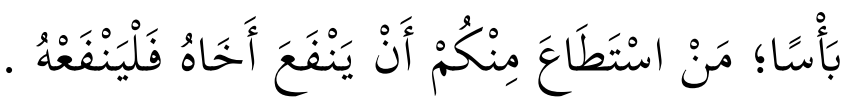

Artinya:

"Dari sahabat Jābir, ia berkata: Rasul melarang penggunaan mantra. Datanglah keluarga 'Amr bin Hazm kepada Nabi dan bertanya: wahai Rasul, kami memiliki mantra untuk mengobati sengatan kalajengking sementara engkau melarang menggunakan mantra. Sahabat Jābir berkata: lalu mereka memperlihatkan 
mantra tersebut kepada Nabi. Kemudian Nabi berkomentar: tidak masalah. Siapa pun diantara kalian yang bisa berbagi manfaat kepada saudaranya, lakukan”. (HR. Muslim dan Ahmad).

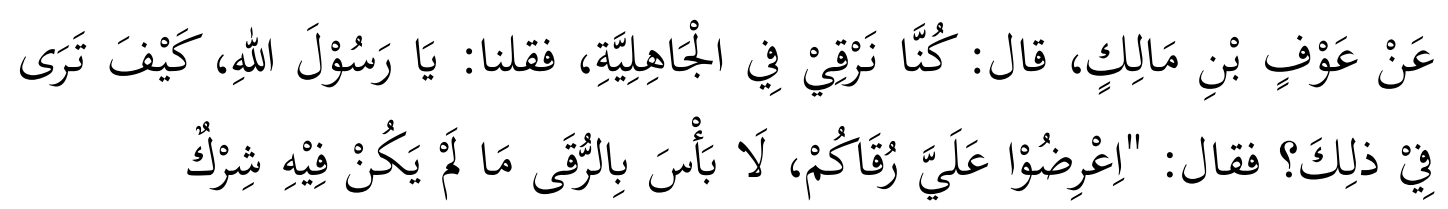

Artinya:

"Dari Sahabat 'Auf bin Mālik, ia bercerita: sebelum masuk Islam, kami terbiasa membaca mantra. Kami bertanya pada Nabi: wahai Rasul, bagaimana pendapatmu? Beliau menjawab: perlihatkan jamppi-jampi kalian padaku. Tidak ada masalah dengan jampijampi selama tidak ada unsur kesyirikan". (HR. Muslim dan Abu Dawud).

\section{Konsep Mitologi Azimat}

Arti dari mitos jika dilihat dari sejarahnya ialah sebuah cerita yang dipraktekkan lewat ritual atau tradisi yang ada di lingkungan masyarakat yang kemudian dipimpin oleh tokoh masyarakat ataupun tokoh agama setempat. Di mana ritual dan tradisi ini sudah ada secara turun menurun hingga sampai detik ini dan sulit untuk ditinggalkan. Sehingga masyarakat secara tidak langsung mengakui kebenaran dari cerita tersebut dan menganggapnya sebagai hal yang patut disakralkan atau disucikan (Sulaichah, 2019, p. 43). Sedangkan mitos yang muncul dalam agama merupakan ekspresi dari masyarakat yang bermacam-macam dan akan muncul pada saat seseorang meyakini bahwa alam itu sebagai objek yang memiliki kekuatan dan pengaruh yang besar sehingga dianggap sakral atau disucikan. Lewat inilah sebuah mitos akan muncul di lingkungan masyarakat, mereka meyakini dan mempercayai bahwa kegiatan itu benar selama tidak keluar dari ajaran Islam maka diperbolehkan dan tindakan yang dilakukan hanyalah sebagai perantara untuk berhubungan kepada Allah SWT. Pada agama Islam hal ini seringkali mendapatkan perdebatan dan sebagian masyarakat menganggap hal ini sebagai perbuatan yang syirik, khurafat, takhayul bahkan ada yang mengatakan bid'ah karena tidak berlandaskan al- Qur'an dan Hadis (Roibin, 2009, p. 72).

Kecenderungan memahami sesuatu berdasarkan informasi yang dimiliki juga terjadi di masyarakat Indonesia dalam memahami agamanya. Ada yang menekankan dimensi intelektual sehingga dalam keberagamaan cenderung mencari dalil yang ada dalam dua sumber utama. Namun ada juga yang mengedepankan dimensi mistik, sosial, dan ritual dengan pendekatan yang bervariasi (Muhammad Alfatih Suryadilaga, 2010, p. 183). Pun demikian dalam masalah azimat ini. Ada yang dalam pencariannya hanya berhenti pada al-Qur'an dan hadis sebagai acuan pemahamannya. Adapula yang melangkah lebih jauh lagi yakni mencari tahu relevansi informasi yang disuguhkan oleh dua sumber utama tersebut dengan kondisi sosiologis, historis, dan lainnya pada saat informasi tersebut muncul. Pelibatan dimensi mistik, sosial, dan ritual dengan pendekatan yang 
bervariasi sangat bermanfaat. Sebagaimana ungkap Mahmud Syaltut: "mengetahui hal-hal yang dilakukan Nabi dengan mengaitkannya pada fungsi Nabi ketika hal itu dikerjakan sangat besar manfaatnya" (Ali, 2001, p. 96).

Mereka yang anti terhadap azimat adalah masyarakat yang getol terhadap pemurnian ajaran Islam. Umumnya, mereka terpengaruh oleh paham salafi yang di Indonesia muncul pada tahun 1980-an. (Mudzhar, 2012, p. 23-24). Dalam memahami teks keagamaan, dalam hal ini hadis Nabi, mereka terkenal "rigid", kaku, dan tekstual. (Fitriani, 2016, p. 7). Menurut mereka, bahasa wahyu yang disampaikan oleh Nabi adalah bahasa yang istimewa. Meskipun sama-sama berbahasa Arab, bahasa wahyu diyakini sangat sakral dan tidak memerlukn adanya penakwilan. Dari sini, pemaknaan secara kebahasaan sebagaimana lazimnya digunakan dan dipahami oleh para penuturnya lebih mereka pilih (Nadia, 2017, p. 168).

Sebelum menyajikan dua pemahaman mengenai mitos azimat dengan menggunakan semiologinya Barthes, rasanya perlu ditegaskan terlebih dahulu mengenai dua hal; unsur yang terlibat dalam azimat dan mitos azimat yang disepakati keharamannya. Mengacu pada teori Barthes, bagian azimat yang menjadi tanda adalah kata azimat itu sendiri. Penandanya berupa kalung, gelang, cincin, kertas, atau kain. Adapun petandanya adalah tulisan khusus yang ada kalanya tidak bisa dipahami sama sekali dan bisa dipahami yang disertai dengan ayat al-Qur'an, asma Allah atau bacaan yang diajarkan Nabi. Saat benda yang berupa kalung, gelang, rajah atau cincin bertemu dengan tulisan khusus terbentuklah azimat. Kurang lebih begitulah analisis pada tataran bahasa tingkatan pertama.

Masuk pada analisis bahasa kedua, muncul mitos-mitos azimat yang disikapi berbeda oleh masyarakat. Dari sekian mitos yang ada, terdapat jenis mitos yang disepakati keharamannya. Terdapat dua penyebab yang menjadikan azimat dihukumi haram mutlak oleh dua kelompok masyarakat ini. Pertama, penggunaan bahasa asing yang tidak dimengerti maknanya baik dalam mantra maupun azimat sehingga dikhawatirkan adanya unsur sihir dan kekufuran (Ābādī, 1968, 10:367, al-Saharanfūrī, n.d., 16:213). Keharaman ini sudah terdeteksi saat azimat ditelaah pada tataran bahasa tingkatan pertama. Namun demikian, ia tetap bisa masuk pada tataran mitos pada saat dipertemukan dengan petanda II yang berupa kekhawatiran akan adanya unsur syirik atau kekufuran. Kedua, adanya keyakinan bahwa kekuatan atau efek yang dihasilkan berasal dari benda itu sendiri (alSaharanfürī, n.d., 16:213). Faktor kedua lebih pada makna konotasi yang dijadikan sebagai petanda II. Petanda II ini tidak membedakan antara makna denotasi (petanda I) yang digunakan, apakah berupa kalimat yang tidak bisa dipahami maknanya atau kalimat tayyibah yang jelas-jelas dilegalkan. Berikut ini gambaran daripada bagan mitos azimat yang disepakati keharamannya: 


\begin{tabular}{|l|l|l|}
\hline $\begin{array}{l}\text { 1. Penanda } \\
\text { Kalung, gelang, cincin, } \\
\text { kertas, atau kain }\end{array}$ & $\begin{array}{l}\text { 2. Petanda } \\
\text { Bertuliskan kalimat } \\
\text { yang tidak jelas }\end{array}$ & \\
\hline $\begin{array}{l}\text { 3. Tanda } \\
\text { Azimat }\end{array}$ & $\begin{array}{l}\text { Dikhawatirkan anda an syirik atau } \\
\text { unsur } \\
\text { kekufuran }\end{array}$ \\
\hline $\begin{array}{l}\text { III. Penanda } \text { Tanda } \\
\text { Azimat sebagai bentuk kemusyrikan (haram) }\end{array}$ \\
\hline
\end{tabular}

Gambar 2. Mitos Azimat Disepakati Keharamannya Lantaran Petanda Dan Konotasi Yang Disematkan

\begin{tabular}{|l|l|l|}
\hline $\begin{array}{l}\text { 1. Penanda } \\
\text { Kalung, gelang, cincin, } \\
\text { kertas, atau kain }\end{array}$ & $\begin{array}{l}\text { 2. Petanda } \\
\text { Bertuliskan ayat atau } \\
\text { asma Allah }\end{array}$ & \\
\hline $\begin{array}{l}\text { 3. Tanda } \\
\text { Azimat } \\
\text { I. Penanda }\end{array}$ & $\begin{array}{l}\text { Berisi kekuatan murni } \\
\text { dari dirinya sendiri } \\
\text { II. Petanda }\end{array}$ \\
$\begin{array}{ll}\text { III. Tanda } \\
\text { Azimat sebagai bentuk kemusyrikan (haram) }\end{array}$ \\
\hline
\end{tabular}

Gambar 3. Mitos Azimat Yang Disepakati Keharamannya Lantaran Konotasi Yang Disematkan

Dengan berpegang pada hadis yang bersifat umum (tidak di-takhșiș), mereka memutlakkan pengharam azimat. Bahkan seandainya azimat tersebut menggunakan media ayat, asma Allah, atau redaksi yang diperkenalkan oleh Nabi melalui hadisnya, mereka tetap mengharamkannya. Sikap mereka ini lebih sebagai bentuk pencegahan agar tidak terjatuh dalam kesyirikan lantaran keyakinan yang keliru. Selain itu, juga dalam rangka mengantisipasi terjadinya penisataan ayat al-Quran saat azimat yang terbuat darinya dibawa masuk ke tempat yang terlarang (Sahad, 2015, p. 26). Berikut ini adalah gambaran daripada bagan mitos azimat yang dipegang oleh paham salafi:

\begin{tabular}{|c|c|c|}
\hline $\begin{array}{l}\text { 1. Penanda } \\
\text { Kalung, gelang, cincin, } \\
\text { kertas, atau kain }\end{array}$ & $\begin{array}{l}\text { 2. Petanda } \\
\text { Bertuliskan ayat atau } \\
\text { asma Allah }\end{array}$ & \\
\hline \multicolumn{2}{|l|}{$\begin{array}{l}\text { 3. Tanda } \\
\text { Azimat } \\
\text { I. Penanda }\end{array}$} & $\begin{array}{l}\text { Berisi kekuatan yang } \\
\text { akan berfungsi atas ijin } \\
\text { Allah } \\
\text { II. Petanda }\end{array}$ \\
\hline \multicolumn{3}{|c|}{$\begin{array}{l}\text { III. Tanda } \\
\text { Azimat sebagai bentuk kemusyrikan (haram) }\end{array}$} \\
\hline
\end{tabular}

Gambar 4. Mitos Azimat Versi Kelompok Salafi 
Tidak ada mitos yang universal pada suatu kebudayaan. Yang ada adalah mitos yang dominan namun di satu sisi ada yang memiliki kontramitos, yakni subkultur dalam masyarakat yang memiliki mitos berbeda dengan mitos yang dipahami mayoritas (Friske, 2007, p. 124). Arkoun juga menegaskan hal ini bahwa setiap kelompok masyarakat memiliki mitos yang berbeda-beda sesuai dengan sosial dan kulturalnya masing-masing (Roibin, 2009, p. 93). Mengenai mitos azimat yang disampaikan kaum salafi tadi, ada kelompok lain yang menerimanya dengan persyaratan tertentu. Pada umumnya, mereka adalah orang-orang yang mengadopsi hasil pemahaman ulama atau tokoh masyarakat. Bahkan mereka menjadi kelompok mayoritas yang tidak mengamalkan ajaran Islam secara langsung dari al-Qur'an dan hadis. Mereka lebih memilih mengadopsi pemahaman ulama yang berhasil memahami isi dan kandungan ajaran Islam dari sumber pokok dengan relatif baik (Khaziq, 2009, p. 13). Dari fenomena ini, mitos azimat sebagai sesuatu yang diperbolehkan bernilai lebih kuat dibanding mitos pengharaman azimat. Berikut ini gambaran daripada bagan mitos azimat menurut mayoritas tersebut:

\begin{tabular}{|l|l|l|}
\hline $\begin{array}{l}\text { 1. Penanda } \\
\text { Kalung, gelang, cincin, } \\
\text { kertas, atau kain }\end{array}$ & $\begin{array}{l}\text { 2. Petanda } \\
\text { Bertuliskan ayat atau } \\
\text { asma Allah }\end{array}$ & \\
\hline $\begin{array}{l}\text { 3. Tanda } \\
\text { Azimat }\end{array}$ & $\begin{array}{l}\text { Berisi kekuatan yang } \\
\text { akan berfungsi atas ijin } \\
\text { Allah } \\
\text { II. Petanda }\end{array}$ \\
\hline $\begin{array}{l}\text { III. Penanda } \text { Tanda } \\
\text { Azimat sebagai bentuk tabarruk (dianjurkan) }\end{array}$ \\
\hline
\end{tabular}

Gambar 5. Mitos Azimat Versi Kelompok Mayoritas

Kelompok mayoritas yang berpegang pada pemahaman ulama ini, diantaranya berpegang pada penjelasan Abu Tayyib terhadap dua hadis yang dijadikan pegangan oleh kelompok salafi. Pensyarah kitab Sunan Abū Dāwud ini menjelaskan bahwa tidak semua yang dicakup hadis ini bernilai syirik. Harus dibedakan antara mantra yang tidak dimengerti kontennya dengan mantra yang dipahami kontennya dan mengandung asma Allah, tamimah yang berisi asma Allah, ayat, dan doa yang diajarkan Nabi dengan yang bukan (Ābādī, 1968, 10:367). Selain itu, pemahaman yang tepat terhadap kata syirik juga dipandang perlu. Al-Saharanfürī mendefiniskan kata ini sebagai salah satu bentuk perilaku orang musyrik atau sesuatu yang bisa membawa pada kemusyrikan jika terdapat keyakinan akan efek yang dimilikinya (al-Saharanfūrī, n.d., 16:213). Dengan kata lain, apabila hal itu tidak ditemui maka penggunaan azimat diperbolehkan sebagaimana yang ditegaskan juga oleh Abu țayyib (Ābādī, 1968, 10:367). Adapun mengenai dua hadis riwayat imam Muslim yang bisa dijadikan rujukan langsung, sudah sangat jelas sekali bahwa pada hadis dengan nomor 5625 Nabi menegaskan kebolehan menggunakan mantra selama tidak ada unsur kesyirikan. Kemudian hadis dengan nomor 5624 yang terdapat larangan 
penggunaan mantra (innaka nahaita 'an al-ruqā), para ulama memahami larangan tersebut dalam tiga bentuk. 1) Pada awalnya ada larangan penggunaan mantra namun kemudian ia dihapus (diperbolehkan) dan menjadi ketetapan syariat. 2) Larangan tersebut berlaku untuk mantra yang tidak diketahui, bukan berbahasa Arab, dan tidak dipahami artinya. Agama mencela penggunaan mantra dengan jenis ini karena adanya kemungkinan unsur kekafiran atau yang mendekatinya. Adapun bermantra dengan ayat dan zikir tidaklah mengapa bahkan bernilai sunnah. 3) Larangan ini berlaku bagi mereka yang meyakini kemanfaatan mantra tersebut berasal dari dirinya sendirinya sebagaimana keyakinan masyarakat Jahiliyah terhadap berbagai azimat. Pandangan yang membolehkan ini diperkuat dengan infornasi pemilah-milahan Nabi terhadap redaksi mantra yang diperlihatkan kepadanya (al-Bannā, n.d., p. 177-178).

\section{KESIMPULAN}

Dalam menerima segala sesuatu, Islam selalu mengajak kepada pemeluknya untuk waspada. Ia harus dicerna terlebih dahulu untuk diambil yang sesuai dengan syariat, diperbaiki atau dimodifikasi bagian yang masih bisa diselamatkan, atau bahkan harus ditinggalkan sama sekali lantaran bertentangan. Begitulah yang terjadi saat proses waris-mewaris budaya peninggalan leluhur yang berbentuk benda. Jikalau Nabi dan para sahabatnya mengenal tamimah, masyarakat Indonesia mengenal azimat. Nabi sangat hatihati dalam menerima benda yang menjadi bentuk representasi budaya Arab ini. Baginya, hal itu tidaklah masalah selama tidak ada unsur kesyirikan, baik dari benda itu sendiri maupun penggunanya. Pun dengan masyarakat Indonesia yang menjadi kelompok terbesar yang mengikuti ajarannya. Kendati demikian, dengan berpegang pada hadis Nabi, ada sebagian masyarakat yang menolak penggunaan azimat lantaran kekhawatirannya terhadap dosa syirik dan pelecehan ayat suci al-Qur'an.

Fenomena azimat yang terjadi di Indonesia ini, terasa lebih menarik saat pengkajiannya melibatkan teori semiologi Roland Barthes. Dengan teori signifikasi dan mitosnya, Barthes berhasil memperlihatkan kepada pembaca mitos akan unsur-unsur yang terlibat dalam mitos tersebut. Berkenaan dengan mitos azimat ini, pada tataran bahasa tingkatan pertama Barthes mampu memberitahu masyarakat dengan mudah bahwa petanda yang ada dalam azimat bisa berupa tulisan atau bacaan kalimat yang diperbolehkan dan tidak. Kemudian pada tataran bahasa tingkatan kedua (mitos), muncul dua hal (tanda) yang jauh berbeda dari satu hal yang eksistensinya sama (penanda berupa azimat dan petanda berupa kekuatan yang akan berfungsi atas ijin Allah), yakni mitos azimat sebagai bentuk kemusyrikan yang diharamkan dan mitos azimat sebagai bentuk tabarruk yang dianjurkan. Kemusyrikan ini juga lahir dari dua petanda lain, yakni kekhawatiran akan adanya unsur kemusyrikan atau kekufuran dalam petanda tingkat satu yang berupa kalimat tidak jelas maknanya dan keyakinan akan kekuatan yang diyakini muncul dari azimat itu sendiri. Dua jenis mitos terakhir ini disepakati keharamannya oleh umat Islam. 


\section{REFERENSI}

\section{Buku}

Ābādī, A. Ṭayyib M. S. al-Haqq al-'Aẓìm Ā. (1968). 'Aun al-Ma’būd Syarh Sunan Abì Dāwud (Vol. 10). Muhammad 'Abdul Muhsin.

Al-Bannā, A. 'Abdurraḥmān. (n.d.). Al-Fatḥ al-Rabbān̄̄ li Tartīb Musnad alImām Ahmad bin Hambal al-Syaibānī (Vol. 17).

Al-Gūrī, S. A. M. (2009). Al-Waj̄̄z fì Ta'rīf Kutub al-Hadīs. Dar ibn Katsir.

Al-Naisābūrī, A. al-Ḥusain M. bin al-Hajjāj al-Qusyairī. (2003). Śaḥ̄ḥ Muslim. Dar al-Fikr.

Al-Saharanfūrī, K. A. (n.d.). Bażlu al-Majhūd fì Halli Abì Dāwud (Vol. 16). Dar al-Kutub al-'Ilmiyyah.

Al-Sijistānī, A. D. S. bin al-Asy’aś. (n.d.). Sunan Abī Dāwud. Bait al-Afkar.

Hazm.

. (1997). Sunan Abì Dāwud (Vol. 4). Dar Ibn

Ali, N. (2001). Memahami Hadis Nabi: Meotde dan Pendekatan. CESaD YPI alRahmah.

Barthes, R. (2010). Membedah Mitos-Mitos Budaya Massa. Jalasutra.

Budiman, K. (2011). Semiotika Visual. Jalasutra.

Friske, J. (2007). Cultural And Communication Studies, (terj). Jalasutra.

Ibn Hambal, A. (1999a). Musnad al-Imām Ahmad bin Hanbal (Vol. 33). alRisalah.

Risalah.

. (1999b). Musnad al-Imām Aḥmad bin Hanbal (Vol. 28). al(1999c). Musnad al-Imām Aḥmad bin Hanbal (Vol. 22). alRisalah.

Kaelan. (2017). Filsafat Bahasa dan Hermeneutika. Paradigma.

Khaziq. (2009). Islam dan Budaya Lokal, Belajar Memahami Realitas Agama dalam Masyarakat. Teras.

Mubarak, A. Z. (2007). Pendekatan Strukturalisme Linguistik dalam Tafsir alQur'an Kontemporer "ala” M. Syahrur. eLSAQ Press.

Mudzhar, M. A. (2012). Menjaga Aswaja dan Kerukunan Umat. Puslitbang Kemenag RI.

Muhammad, N. H. (2012). Benteng Ahlussunah wal Jamaah, Menolak Faham Salafi, Wahabi, MTA, Hizbut Tahrir dan LDII. Nasyrul 'Ilmi.

Mustaqim, dkk., A. (2008). Paradigma Integrasi-Interkoneksi dalam Memahami Hadis. UIN Sunan Kalijaga.

Nasution, dkk, H. (1992). Ensiklopedi Islam Indonesia. Djambatan.

Nurdin, A. (2015). Komunikasi Magis: Fenomena Dukun di Pedesaan. LkiS.

Pamungkas, R. (2007). Mengenal Keris, Senjata Magis Masyarakat Jawa. Narasi.

Purwadi, \& et.al. (2005). Ensiklopedi Kebudayaan Jawa. Bina Media.

Rahtikawati, Y., \& Rusmana, D. (2013). Metodologi Tafsir al-Qur'an; Strukturalisme, Semantik, Semiotik, dan Hermeneutik. Pustaka Setia.

Roibin. (2009). Relasi Agama dan Budaya Mayarakat Kontemporer. UINMalang Press.

Sahad, M. N. (2015). Penggunaan Azimat Pelaris Perniagaan menurut Perspektif Akidah Islam. 27. 
Sobur, A. (2014). Komunikasi Naratif, Paradigma, Analisis, dan Aplikasi. Rosdakarya.

Sudjiman, P., \& Zoest, A. van. (1996). Serba-serbi Semiotika. Gramedia Pustaka Utama.

Suryadilaga, M. Alfatih. (2017). Metodologi Syarah Hadis dari Klasik Hingga Kontemporer. Kalimedia.

Konteks. Teras.

(2010). Aplikasi Penelitian Hadis: Dari Teks ke

Suyono, Capt. R. P. (2007). Dunia Mistik Orang Jawa, Roh, Ritual, Benda Magis. LkiS.

Takwin, B. (2009). Akar-akar Ideologi. Jalasutra.

Umar, N. (2014). Deradikalisasi Pemahaman al-Qur `an dan Hadis. Elex Media Komputindo.

\section{Jurnal dan lainnya}

Dwiatmojo, G. N. (2018). Azimat dan Rajah dalam Catatan Pengikut Tarekat Naqsabandiyah di Desa Lebak Ayu Kabupaten Madiun Pertengahan Abad ke-20. Manuskripta, 8 (1), 75-106. https://doi.org/10.33656/manuskripta.v8i1.102

Fitriani, M. I. (2016). Manajemen Konflik Berbasis "Multicultural Competences": Solusi Alternatif Kontestasi Pribumi dan Salafi di Lombok. eL-Harakah, $18 \quad$ (1), 18. https://doi.org/10.18860/el.v18i1.3459

Hs, Y. T. (2017). Batu Akik Sebagai Budaya Populer. Jurnal Artefak, 4 (1), 1-8. https://doi.org/10.25157/ja.v4i1.705

Machmudah, U. (2016). Budaya Mitoni: Analisis Nilai-Nilai Islam dalam Membangun Semangat Ekonomi. el-Harakah, 18 (2), 185-198. https://doi.org/10.1886o/el.v18i2.3682

Meganingrum, R., \& Fauziah, N. (2017). Hubungan Antara Identitas Sosial Dengankecenderungan Perilaku Konsumtif Padapenggemar Batuakik Dan Batu Muliadi Semarang. Jurnal EMPATI, 6 (1), 365-373.

Nadia, Z. N. (2017). Perilaku Keagamaan Komunitas Muslim (Pemahaman Hadis dalam NU dan Salafi Wahabi di Indonesia). Jurnal Living Hadis, 2(2), 141-177. https://doi.org/10.14421/livinghadis.2017.1327

Sulaichah, D. A. N. (2019). Mitos Kue Apem Dalam Tradisi Selamatan Kematian (Tahlilan) Perspektif Teori Semiologi Roland Barthes di Desa Kedung Baruk Rungkut Surabaya, (Skripsi). UIN Sunan Ampel.

Zamzami, M. (2018). Konstruksi Sosial_Teologis Ritual Ijazah Asma' Artho (Uang Azimat) di Pondok Pesantren Fathul Ulum Kwagean Pare Kediri. Islamica: Jurnal Studi Keislaman, 12 (2), 306-332. https://doi.org/10.15642/islamica.2018.12.2.288-314 